\title{
Production of physic nut hybrid progenies and their parental in various dry land
}

\author{
Maftuchah $^{1^{*}}$, Agus Zainudin $^{1}$, Hadi Sudarmo ${ }^{2}$ \\ ${ }^{1}$ Directorate of Research and Community Services, University of Muhammadiyah Malang, Malang, Indonesia; \\ *Corresponding Author: maftuchah umm@yahoo.com \\ ${ }^{2}$ Indonesian Sweetener and Fiber Crops Research Institute (ISFCRI), Malang, Indonesia
}

Received 26 October 2012; revised 30 November 2012; accepted 19 December 2012

\section{ABSTRACT}

Hibridization is one of breeding strategy to increase productivity of crop including physic nut (Jatropha curcas Linn.). This study aimed to obtain information productivity per hectare and seed oil content of 11 numbers of physic nut hybrids and their parental in four dry lands. The research was conducted in four dry land: Kalipare-Malang, Oro-oro Pule-Kejayan Pasuruan, Kedung Pengaron-Pasuruan and Jorongan-Leces Probolinggo. The materials used in this research are the eleven result numbers of physic nut hybrids, they are SP38 $\times$ HS49, SP8 $\times$ HS49, SP8 $\times$ SP16, SP8 $\times$ SP38, SP33 $\times$ HS49, SM35 $\times$ HS49, SM35 $\times$ SP38, IP1A $\times$ HS49, IP1A $\times$ SP38, IP1P $\times$ HS 49, IP1P $\times$ SP38, and their parental, they are HS49, SP16, SP38, SP8, SP33, SM35, IP1A, IP1P, IP3P. Observation was done during the plants' generative phase, on the second harvest. The results showed that SP38XHS49 hybrid on Kedung Pengaron, produces the highest seeds dry weight per hectare $(1170 \mathrm{~kg} / \mathrm{ha})$ with 62.33 gram of dry weight of 100 seeds and the oil content is $32.56 \%$. The highest average of dry seed productions from all planting sites achieved on the crossing between SP38 $\times$ HS49 $(658.75 \mathrm{~kg} / \mathrm{hectare})$ and followed by SP8 $\times$ HS49 $(607.5 \mathrm{~kg} / \mathrm{hectare})$. If the comparison of the four locations, the highest average productivity of physic nut achieved on location Jorongan, Leces, Probolinggo. In general, the data proves that the hybrid result from the crossing shows the higher production level compare to their parental. The dry weight of 100 seeds produced ranged from 54.03 grams to 68.29 grams. Of all four planting sites, it shows that the highest 100 seeds dry weight achieved by the crossing between IP1PXHS49 which is 64.63 grams. The seed oil content ranged from 27.04 to 35.24 percent. The highest average of seed oil content achieved by the crossing between SM35 × SP38 (32.035\%).

Keywords: Physic Nut; Jatropha curcas Linn.; Hybrids; Dry Lands; Second Harvest

\section{INTRODUCTION}

Indonesia as a tropical country, has the potential of natural resources. Agricultural business is a business which very potential to be developed in Indonesia because Indonesia has the potential land resources, agroclimate and adequate human resources. Conditions of a tropical climate with sufficient rainfall, the availability of land, and has been the development of production optimization technologies can support the feasibility of developing biofuels. Biofuel is one of biomass energy in the liquid form, such as biodiesel, bioethanol and biooil. Biofuels are fuels from biological sources (renewable energy). In Indonesia there are 49 types of plants that can be used as an energy source. Some of the plant as a potential biodiesel is oil palm, coconut, jatropha, cotton and canola. But, in addition to the potential for producing bioenergy, some commodities, such as oil palm, coconut, cotton, cassava, sugar cane, and sago, is also a source of commodities for food and feed. Development of food commodities as a source of bioenergy feedstock because it is considered unethical to compete with food and feed ingredients. Advantages of physic nut (Jatropha curcas Linn.) oil as biodiesel oil excluding edible oil category (edible oil) so that their use does not interfere with the supply of edible oil requirement. In addition to developed areas dry and marginal lands. Potential dry land region of eastern Indonesia area \pm 20 million ha. Besides, there are other benefits that can be developed as an ingredient for the manufacture of soap, medicines, chemicals and cake/waste to organic fertilizer because it contains nitrogen and other organic materials. To make jatropha as an either-scale farming households and small 
and medium scale large, growing conditions and cultivation techniques need to be well known because it influences on productivity. Besides that, it is necessary the existence of high-yielding varieties that have high production potential, especially on dry land.

Biodiesel has several advantages over other energy sources that is more environmentally friendly because it produces better emissions, higher combustion efficiency, biodegradable, renewable and increase self-sufficiency in fuel supply, as it can be produced locally [1]. In 2025, Indonesia's biodiesel needs is predicted to reach totally more than 7 million tons of biodiesel [1]. Jatropha is one of the oil plant producers, which can be processed to be the substitute fuel for diesel. Some reasons why the researcher chooses: Jatropha's oil cannot be used for cooking oil, it can be planted with other crops, it can be used as an alternative crop on marginal land and dry climate, it can be used as the greening plants, it can be produced up to the age more than 30 years, as an additional source of income for farmers on marginal land, and its cultivation and technology processing is quiet easy, and it allows to be processed from household industry scale up to large industry.

Jatrophas' productivity level is influenced by the use of genetic potential of seeds, environmental conditions and crop's technology management. Although Jatropha plants are known to grow in dry climates and marginal land, does not mean that these plants do not require water and optimum supply of nutrients for optimum production. The Indonesian's Directorate General of plantations in attempt to fulfill Jatropha superior seed, starting in 2005/ 2006 has built a garden area of 50 hectares of seed parent and the rest is expected from the role of the community or private parties [2]. In Indonesia, the Jatropha germ plasm collection started in 2005-2006, limited to nine provinces covering 54 districts where it has collected more than 200,000 plants from cuttings and seeds, planting material was planted in three gardens they are Pakuwon-Sukabumi, Muktiharjo-Pati, and Asembagus-Situbondo. This material has been selected for 2006 and resulted in three populations of each IP1P, IP1M, IP1A [3]. Sudarmo have identified seven accessions physic nut which has high productivity expectations [4]. Sri Yulaikhah and Kholid crossing the accessions which have hight productivity [5]. However, the overall accession obtained proved to require a substantial input to support the production, besides that it is less tolerant of drought. The development area of physic nut in an effort to supply biodiesel raw material in Indonesia is predicted in 2025 about 2.4 million ha, but the land cultivation of physic nut it is preferred on dry land and non-productive land [6].

In plant's breeding activities, crossing is one of the important processes in the assembly of plant varieties to produces desirable progenies. The terminology of plant breeding is identical by crossing different varieties or species to obtain the desired type [7]. The research team has conducted various crossing accession activities of physic nut to get result of crossing that has a high production potential and drought tolerant [8]. Preliminary testing results shows 100 seed weight ranged from 62.59 grams to 75.48 grams [8], and the eleven numbers crossing result and its nine elders, are then tested on four field site planting [9].

The purpose of this research is to obtain information productivity per hectare and seed oil content eleven numbers of physic nut hybrids and their parental in four dry lands.

\section{MATERIALS AND METHODS}

\subsection{Research Sites}

This research was conducted at four dry land locations which were located in Oro-oro Pule village, Kejayan-Pasuruan Regency; Kedung Pengaron village, Pasuruan Regency; Kalipare village, Malang Regency; and Jorongan Village, Leces-Probolinggo Regency, Indonesia. In this research, the planting on each research sites are done by four repetitions, each repetition are done with 10 plants. The general climate information on each planting sites are shown on the Table 1 below.

\subsection{Planting Material}

The planting materials used are in the form of $30 \mathrm{~cm}$ long stem cuttings of J. curcas L. with its diameter between 2.5 to $3.0 \mathrm{~cm}$ cuttings. The materials used are the eleven result numbers of physic nut hybrids, they are: SP38 $\times$ HS49, SP8 $\times$ HS49, SP8 $\times$ SP16, SP8 $\times$ SP38, XHS 49, SM35 $\times$ HS49, SM35 $\times$ SP38, IP1A $\times$ HS49, $\mathrm{IP} 1 \mathrm{~A} \times \mathrm{SP} 38, \mathrm{IP} 1 \mathrm{P} \times \mathrm{HS} 49, \mathrm{IP} 1 \mathrm{P} \times \mathrm{SP} 38$, and nine of their parental, they are: HS49, SP16, SP38, SP8, SP33, SM35, IP1A, IP1P [10]. General information of planting materials are shown on the Table 2 below.

\subsection{The Implementation of Research Activities}

The aeration holes are main requirements because the roots of physic nut is resistant to pool of water. Physic nut plant nursery is done by using polybag $15 \times 25 \mathrm{~cm}$ sized with aeration holes on each side of the polybag.In the preparation the planting medium, chunks of land crushed and then continue filtered and mixed with manure. The media used in this research is soil and manure with the ratio $3: 1$. The media put into the polybag with approximately $3 / 4$ of the polybag and then organized neatly on the prepared nursery seedbed. The polybags are neatly arranged and were each given a crossing code number, which the seeds will be planted. 
Table 1. 2011 Climatology data on each planting sites (Source: Climatology center, East Java Indonesia).

\begin{tabular}{|c|c|c|c|c|c|c|c|c|c|c|c|c|c|}
\hline Location & General Climate & Jan & Feb & March & April & May & June & July & August & Sept & Oct & Nov & Dec \\
\hline \multirow{4}{*}{ Kedung Pengaron, Pasuruan } & Presipitation (mm) & 201 & 139 & 286 & 340 & 230 & 0 & 0 & 0 & 0 & 0 & 197 & 216 \\
\hline & Rain Day (days) & 14 & 9 & 19 & 15 & 11 & 0 & 0 & 0 & 0 & 0 & 9 & 15 \\
\hline & Maximum Rain (mm) & 46 & 50 & 50 & 89 & 92 & 0 & 0 & 0 & 0 & 0 & 76 & 38 \\
\hline & $\begin{array}{c}\text { Average } \\
\text { Temperature }\left({ }^{\circ} \mathrm{C}\right)\end{array}$ & & & & & & 29.8 & & & & & & \\
\hline \multirow{4}{*}{ Oro-Oro Pule, Kejayan Pasuruan } & Presipitation (mm) & 199 & 134 & 280 & 337 & 228 & 0 & 0 & 0 & 0 & 0 & 189 & 209 \\
\hline & Rain Day (days) & 13 & 8 & 17 & 14 & 10 & 0 & 0 & 0 & 0 & 0 & 8 & 13 \\
\hline & Maximum Rain (mm) & 45 & 53 & 49 & 89 & 129 & 0 & 0 & 0 & 0 & 0 & 71 & 30 \\
\hline & $\begin{array}{c}\text { Average } \\
\text { Temperature }\left({ }^{\circ} \mathrm{C}\right)\end{array}$ & & & & & & 32.4 & & & & & & \\
\hline \multirow{4}{*}{ Jorongan, Leces Probolinggo } & Presipitation (mm) & 720 & 574 & 477 & 176 & 135 & 12 & 0 & 0 & 0 & 21 & 25 & 294 \\
\hline & Rain Day (days) & 25 & 20 & 23 & 8 & 4 & 2 & 0 & 0 & 0 & 2 & 2 & 14 \\
\hline & Maximum Rain (mm) & 85 & 158 & 56 & 40 & 54 & 7 & 0 & 0 & 0 & 13 & 14 & 87 \\
\hline & $\begin{array}{c}\text { Average } \\
\text { Temperature }\left({ }^{\circ} \mathrm{C}\right)\end{array}$ & & & & & & 29.6 & & & & & & \\
\hline \multirow{4}{*}{ Kalipare, Malang } & Presipitation (mm) & 244 & 193 & 215 & 168 & 132 & 17 & 0 & 0 & 0 & 73 & 244 & 211 \\
\hline & Rain Day (days) & 17 & 11 & 15 & 13 & 9 & 2 & 0 & 0 & 0 & 7 & 18 & 19 \\
\hline & Maximum Rain (mm) & 44 & 50 & 46 & 47 & 49 & 9 & 0 & 0 & 0 & 30 & 23 & 29 \\
\hline & $\begin{array}{c}\text { Average } \\
\text { Temperature }\left({ }^{\circ} \mathrm{C}\right) \\
\end{array}$ & & & & & & 24.7 & & & & & & \\
\hline
\end{tabular}

Table 2. Qualitative character of Jatropha curcas hybrids.

\begin{tabular}{|c|c|c|c|c|c|c|}
\hline & Origin & $\begin{array}{c}\text { Number of leaf } \\
\text { indentation }\end{array}$ & $\begin{array}{c}\text { Color of young } \\
\text { leaf }\end{array}$ & Color of old leaf & $\begin{array}{l}\text { Color of leaf } \\
\text { veins }\end{array}$ & Color of stem \\
\hline HS49 & Nusa Tenggara Timur, Indonesia & $4-6$ & red greeny & dark green & light green & silvery green \\
\hline SP16 & Sulawesi Selatan, Indonesia & $4-6$ & red greeny & dark green & light green & silvery green \\
\hline SP38 & Sulawesi Selatan, Indonesia & $4-6$ & red greeny & dark green & light green & silvery green \\
\hline SP8 & Sulawesi Selatan, Indonesia & $4-6$ & dark green & dark green & light green & silvery green \\
\hline SP33 & Sulawesi Selatan, Indonesia & $4-6$ & red greeny & dark green & light green & silvery green \\
\hline SM35 & Nusa Tenggara Barat, Indonesia & $4-6$ & red greeny & dark green & light green & silvery green \\
\hline IP1A & Nusa Tenggara Barat, Indonesia & $5-6$ & dark green & dark green & light green & light green \\
\hline 1P1P & Lampung and West Java, Indonesia & $4-6$ & red greeny & dark green & light green & silvery green \\
\hline IP1M & NTB and East Java, Indonesia & $4-6$ & dark green & dark green & light green & silvery green \\
\hline $\mathrm{SP} 33 \times \mathrm{HS} 49$ & Hybrid & $4-6$ & red greeny & dark green & light green & silvery green \\
\hline $\mathrm{IP} 1 \mathrm{~A} \times \mathrm{HS} 49$ & Hybrid & $4-6$ & red greeny & dark green & light green & light green \\
\hline $\mathrm{IP1A} \times \mathrm{SP} 38$ & Hybrid & $5-6$ & dark green & dark green & light green & light green \\
\hline 1P1P $\times$ HS49 & Hybrid & $4-6$ & red greeny & dark green & light green & silvery green \\
\hline 1P1P × SP38 & Hybrid & $4-6$ & red greeny & dark green & light green & silvery green \\
\hline SP38 $\times$ HS49 & Hybrid & $4-6$ & dark green & dark green & light green & silvery green \\
\hline SM35 × HS49 & Hybrid & $5-6$ & red greeny & dark green & light green & silvery green \\
\hline SM35 × SP38 & Hybrid & 4 & red greeny & dark green & light green & silvery green \\
\hline SP8 × HS49 & Hybrid & $5-6$ & red greeny & dark green & light green & silvery green \\
\hline $\mathrm{SP} 8 \times \mathrm{SP} 16$ & Hybrid & $4-6$ & red greeny & dark green & light green & silvery green \\
\hline $\mathrm{SP} 8 \times \mathrm{SP} 38$ & Hybrid & $4-6$ & red greeny & dark green & light green & silvery green \\
\hline
\end{tabular}

SM = Sumanto; SP = Supriono; HS = Hadi Sudarmo; IP = Improved Population. 
The making the planting hole is carried out with holes sized $30 \times 30 \times 30 \mathrm{~cm}$ with plant spacing $2 \times 2 \mathrm{~m}$ (the population 2500 plants per hectare). Each holes are filled with $2 \mathrm{~kg}$ of manure per hole. In the planting process, every number of crosses repeated 3 times with a sample of 10 plants per repetition. The artificial fertilizer given was $20 \mathrm{~g}$ of urea, $50 \mathrm{~g} \mathrm{SP}-36$ and $10 \mathrm{~g} \mathrm{KCl}$ in the first year, with the repetition twice: once after one month planting and after the plants start flowering. The planting of seeds in field is done when the seeds of physic nut reach the age of 60 days. There were not any watering given during the plants' growth period in the field, the availability of water depends on the rainy season.

On the second year activities, there were fertilization activities by giving $40 \mathrm{~g}$ of urea, $100 \mathrm{~g}$ SP-36 and $20 \mathrm{~g}$ $\mathrm{KCl}$ on each plants, which are given in two phase. The first fertilization phase were given two weeks after the first harvest, while the second fertilization were given at the second generative phase of early flowering. On the second year of plant caring, there were still no watering treatment given.

\subsection{Observation and Data Analysis}

Observation was performed during the generative phase of plant at the second stage of harvest. The Jatropha's production observation is done to the number of fruits per plants, seeds' dry weight per plant, 100 seed's dry weight, and the oil content [11]. Observation toward the seed dry weight and dry weight of 100 seeds were done periodically on every harvest with the criteria that the Jatropha's fruit color must be yellow. The observation of seed oil content were performed at the end of the research, by using the Soxhlet method. The dry jatropha seeds are weighed about two grams and then grinded. Next, the seeds are put into the soxhlet extraction tube. Cooling water were flown through the condenser, the extraction tube were mounted on the distillation device by using acetone solvent for about four hours. After the residue in the extraction tube are stirred, the extraction then continued by using the same solvent for two hours. Acetone which contains oil extract moved to the clean weighing bottle to know its weight, then evaporated with a water bath until it is slightly solid. The drying continued in the oven until the weight are constant, residue weight in the bottle is stated as fat and oil weight.

The collected data were then calculated its average value and standard deviation, and then displayed in the form of average $( \pm)$ and standard deviation table.

\section{RESULTS}

\subsection{The Production of Seeds Dry Weight per Hectare}

The production of physic nut plant are determined by its seeds dry weight. The average of physic nut hybrid's seeds dry weight production, which had been planted on four site of dryland in generative phase, is shown in Table 3 . Table 3 shows that the highest level of seeds dry weight productions per hectare is reached on the crossing between SP38 $\times$ HS49 in Kedung Pengaron site, Pasuruan $(1170 \mathrm{~kg} /$ hectare). It is then followed by the crossing between SP8XHS49 which is also produced in Kedung Pengaron site, Pasuruan (1110 kg/hectare). However, of all crossing in general, the planting in JoronganLeces, Probolinggo land produced the highest average of physic nut seeds dry weight, which is $562.25 \mathrm{~kg} /$ hectare.

The difference on the level of production among the planting site are highly enough proved. It is shown by the data obtained from Oro-oro Pule planting site at Kejayan Pasuruan, the average level of production from all crossing is only $164.225 \mathrm{~kg} /$ hectare. On each crossing treatment, the average of highest seeds dry weight from all the planting sites are reached on the crossing between SP38 × HS49 (658.75 kg/hectare) and SP8 × HS49 (607.5 $\mathrm{kg} /$ hectare).

The hybrid result from the crossing between SP38XH S49 in Oro-oro Pule Pasuruan, Kedung Pengaron Pasuruan, and Jorongan Probolinggo planting site tend to produce higher seeds dry weight compare to the other result of crossings in same location. However, in Kalipare, Malang, the crossing between SP8XSP38 produces high seeds dry weight. In general, the data shows that the hybrid from the crossing result shows the average of higher-level production compare to its parents.

Figure 1 shows the fruits' morphology of the of Jatropha's SP38XHS49 and SP8XHS49 hybrids produced during the research process. While Figure 2 shows the Morfology of physic nut seeds of 10 numbers hybrids.

\subsection{The Average of 100 Seeds' Dry Weight}

The data shows the dry weight of 100 seeds produced ranged from 54.03 grams to 68.29 grams. The highest dry weight of 100 seeds of physic nut obtained in crosses between IP1P $\times$ HS49 in Kalipare, Malang with dry weight of 100 seeds 68.29 grams. The average dry weight of 100 seeds the highest of the four locations obtained from the cross between IP1P $\times$ HS49 (64.63 grams).

The average of 100 seeds dry weight from twenty number physic nut hybrids cultivation in four dry lands as shown in Figure 3. From all crossing numbers, the average shows that the highest 100 seeds' dry weight is reached in Kalipare-Malang planting site (61.755 gram) (Figure 4). While the average from four planting sites shows that, the result of 100 seeds' dry weight is reached by the crossing between IP1P XHS49, which is 64.63 gram (Figure 3). 


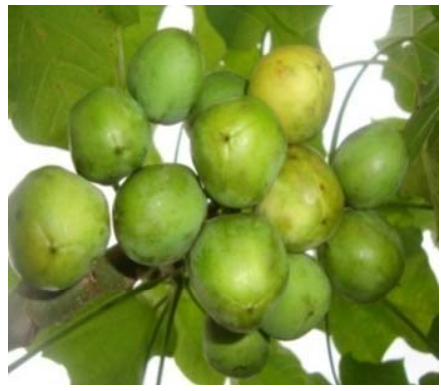

(a)

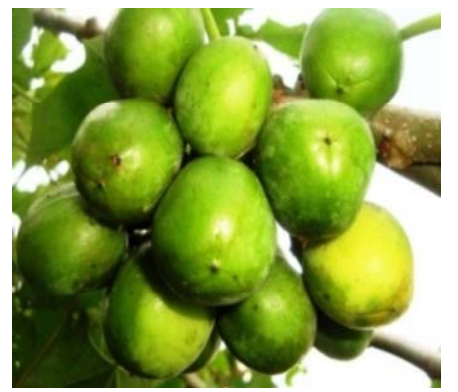

(b)

Figure 1. Fruit morphology of physic nut Hybrids: (a) SP38XHS49 and (b) SP8XHS49 in the second harvest.

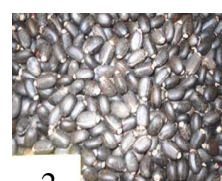

2

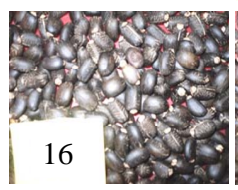

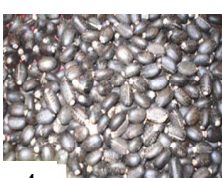
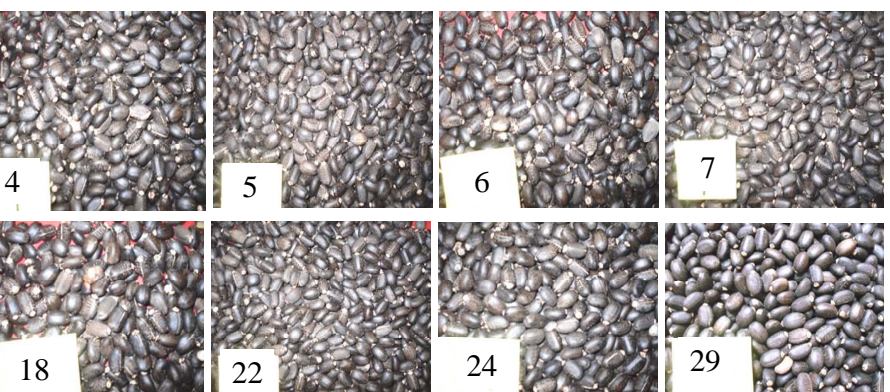

29

Figure 2. Morfology of physic nut seeds of 10 numbers hybrids: (2) SP33XHS49, (4) IP1AXHS49, (5) IP1AXSP38, (6) IP1PXHS49, (7) IP1PXSP38, (16) SP38XHS49, (18) SM35XHS49, (22) SM35XSP38, (24) SP8XHS49, (39) SP8XSP16.

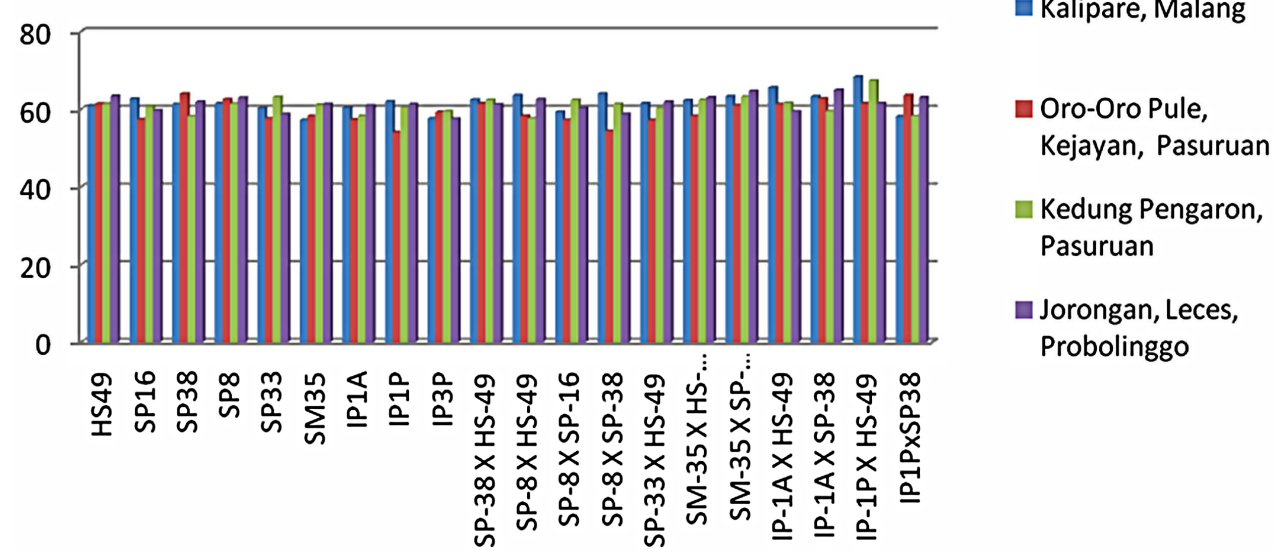

Figure 3. The average of 100 seeds dry weight of physic nut hybrids and their parental in four dry lands.
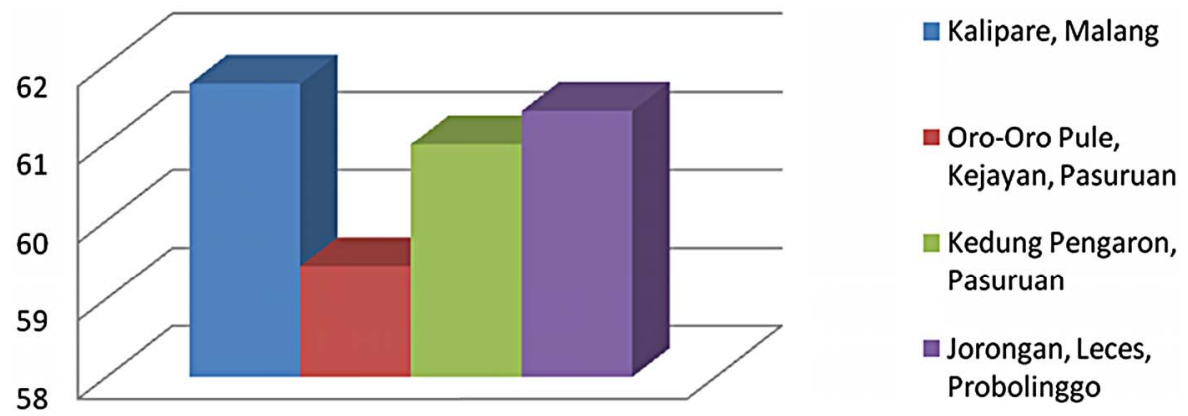

Figure 4. The average of 100 seeds dry weight per plant of physic nut hybrids from four dry lands. 
Table 3. The average of seed dry weight production per hectare of the 20 numbers of physic nut hybrids in four dry lands.

\begin{tabular}{|c|c|c|c|c|c|}
\hline \multirow[b]{2}{*}{ No Crossing } & \multicolumn{5}{|c|}{ The average of seeds dry weight $(\mathrm{kg})$ per hectare \pm SD } \\
\hline & $\begin{array}{l}\text { Kedung Pengaron, } \\
\text { Pasuruan }\end{array}$ & $\begin{array}{l}\text { Oro-Oro Pule, Kejayan } \\
\text { Pasuruan }\end{array}$ & $\begin{array}{l}\text { Jorongan, Leces } \\
\text { Probolinggo }\end{array}$ & Kalipare, Malang & Mean \\
\hline HS49 & $492.5 \pm 0.309$ & $210.0 \pm 0.048$ & $517.5 \pm 0.056$ & $412.5 \pm 0.171$ & 408.13 \\
\hline SP16 & $455.0 \pm 0.182$ & $142.5 \pm 0.019$ & $380.0 \pm 0.060$ & $400.0 \pm 0.098$ & 344.38 \\
\hline SP38 & $337.5 \pm 0.199$ & $155.0 \pm 0.110$ & $262.5 \pm 0.154$ & $142.5 \pm 0.039$ & 224.38 \\
\hline SP8 & $357.5 \pm 0.195$ & $140.0 \pm 0.213$ & $352.5 \pm 0.199$ & $320.0 \pm 0.199$ & 292.50 \\
\hline SP33 & $417.5 \pm 0.209$ & $147.5 \pm 0.108$ & $340.0 \pm 0.279$ & $422.5 \pm 0.309$ & 331.88 \\
\hline SM35 & $495.0 \pm 0.182$ & $117.0 \pm 0.114$ & $405.0 \pm 0.182$ & $470.0 \pm 0.185$ & 371.75 \\
\hline IP1A & $162.5 \pm 0.011$ & $140.0 \pm 0.034$ & $355.0 \pm 0.146$ & $307.5 \pm 0.179$ & 241.25 \\
\hline IP1P & $222.5 \pm 0.010$ & $135.0 \pm 0.029$ & $357.5 \pm 0.195$ & $467.0 \pm 0.127$ & 295.50 \\
\hline IP1M & $495.0 \pm 0.013$ & $230.0 \pm 0.136$ & $580.0 \pm 0.223$ & $395.0 \pm 0.206$ & 425.00 \\
\hline SP33 × HS49 & $355.0 \pm 0.309$ & $127.5 \pm 0.013$ & $863.0 \pm 0.127$ & $277.5 \pm 0.263$ & 406.25 \\
\hline IP1A × HS49 & $442.5 \pm 0.126$ & $127.5 \pm 0.014$ & $500.0 \pm 0.054$ & $570.0 \pm 0.032$ & 410.00 \\
\hline $\mathrm{IP} 1 \mathrm{~A} \times \mathrm{SP} 38$ & $700.0 \pm 0.127$ & $210.0 \pm 0.022$ & $790.0 \pm 0.098$ & $645.0 \pm 0.024$ & 586.25 \\
\hline IP1P × HS49 & $297.5 \pm 0.168$ & $217.5 \pm 0.024$ & $900.0 \pm 0.106$ & $600.0 \pm 0.279$ & 503.75 \\
\hline $\mathrm{IP} 1 \mathrm{P} \times \mathrm{SP} 38$ & $347.5 \pm 0.199$ & $253.0 \pm 0.023$ & $625.0 \pm 0.128$ & $490.0 \pm 0.046$ & 429.38 \\
\hline SP38 × HS49 & $1170.0 \pm 0.207$ & $255.0 \pm 0.027$ & $925.0 \pm 0.124$ & $285.0 \pm 0.246$ & 658.75 \\
\hline SM35 × HS49 & $480.0 \pm 0.182$ & $97.5 \pm 0.008$ & $410.0 \pm 0.043$ & $420.0 \pm 0.457$ & 351.88 \\
\hline SM35 × SP38 & $670.0 \pm 0.192$ & $67.5 \pm 0.014$ & $630.0 \pm 0.060$ & $697.5 \pm 0.173$ & 516.25 \\
\hline $\mathrm{SP} 8 \times \mathrm{HS} 49$ & $1110.0 \pm 0.220$ & $210.0 \pm 0.021$ & $615.0 \pm 0.137$ & $495.0 \pm 0.043$ & 607.50 \\
\hline $\mathrm{SP} 8 \times \mathrm{SP} 16$ & $525.0 \pm 0.271$ & $150.0 \pm 0.011$ & $585.0 \pm 0.060$ & $247.5 \pm 0.208$ & 376.88 \\
\hline SP8 $\times$ SP38 & $357.5 \pm 0.199$ & $150.0 \pm 0.010$ & $850.0 \pm 0.119$ & $865.0 \pm 0.346$ & 555.63 \\
\hline Mean & 494.5 & 164.225 & 562.25 & 446.475 & \\
\hline
\end{tabular}

\subsection{Seeds Oil Content}

Jatropha fruits' harvesting should be done at the fruit appears to have yellowish color. The total harvested seeds will then dried under the sunlight for 5 to 6 days then it is weighed for its dry weight. The dried beans are then analyzed their levels of oil content. The result of Jatropha seeds oil content analysis shows that the average of physic nut seeds oil content is ranging from $27.04 \%$ up to $35.24 \%$ based on the analysis result. The highest content is reached from the crossing result between SM35XSP38 in Kedung Pengaron land, Pasuruan (35.24\%). Of all four dry land planting sites tested, the highest seed oil content is reached by the crossing between SM35XSP38 (32.035\%).

The average of seeds oil content (\%) of physic nut hybrids and their parental in four dry lands, as shown in Figure 5. The highest seed oil content (\%) is reached from SM35XSP38 hybrids (32.035\%). Figure 6 shows the average of seeds oil content (\%) of number of Jatropha's hybrids from four dry lands. From all crossing numbers, the average shows that the highest seed oil content is reached in Kedung Pengaron, Pasuruan (31.41\%).

\section{DISCUSSIONS}

The tendency of crude oil consumption improvement results on the need for renewable energy sources utilization as the important part of energy diversification program. Jatropha is the perennial plant whose seed contains oil, which can be used as the diesel fuel substitute. The purpose of plant crossing is to combine a number of characteristics possessed by the parental genotype so that it will give a number of new genotypes results with the characteristics passed down by their parental. In the jatropha plant which has unisexual flowers where the male flowers and female flowers separate [12] the implementation of crossing is relatively easy to be done, especially 


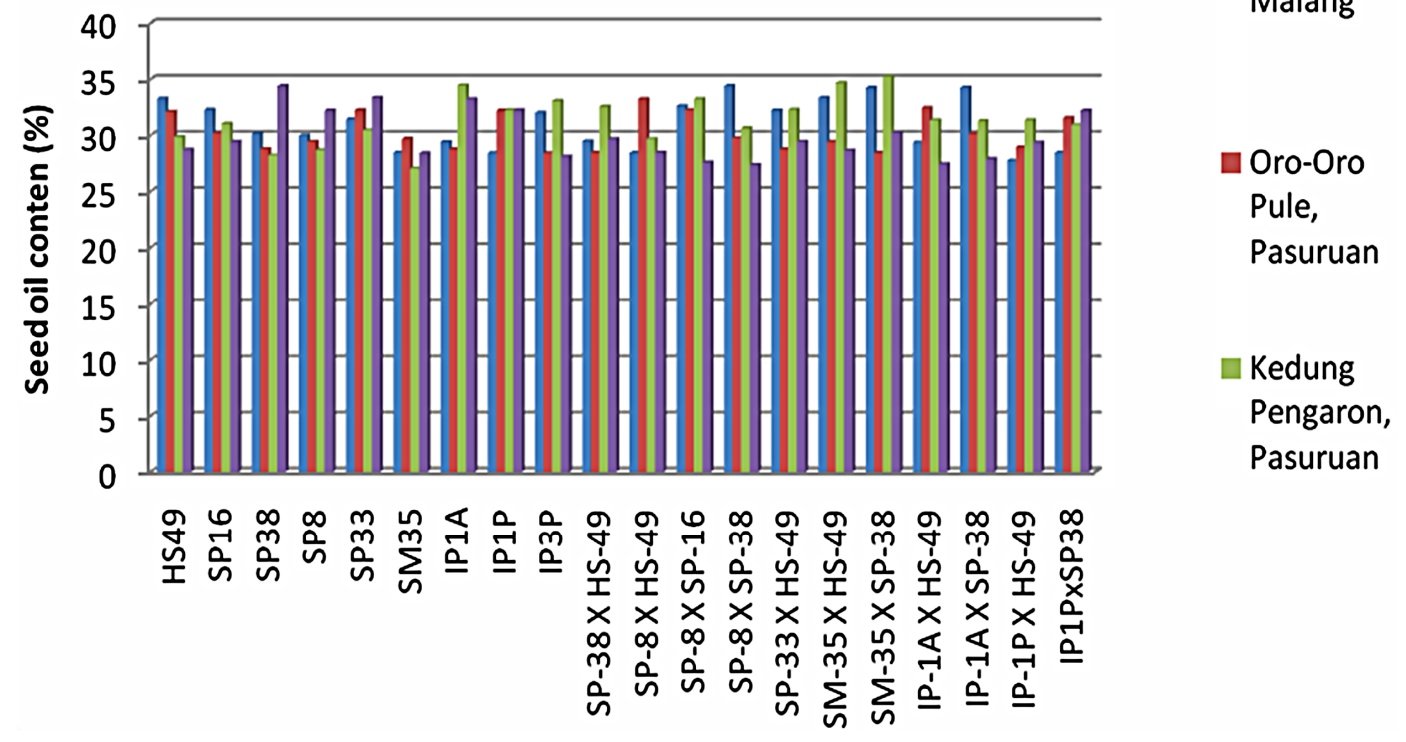

Figure 5. The average of seeds oil content (\%) from twenty number of Jatropha's hybrids in four dry lands.

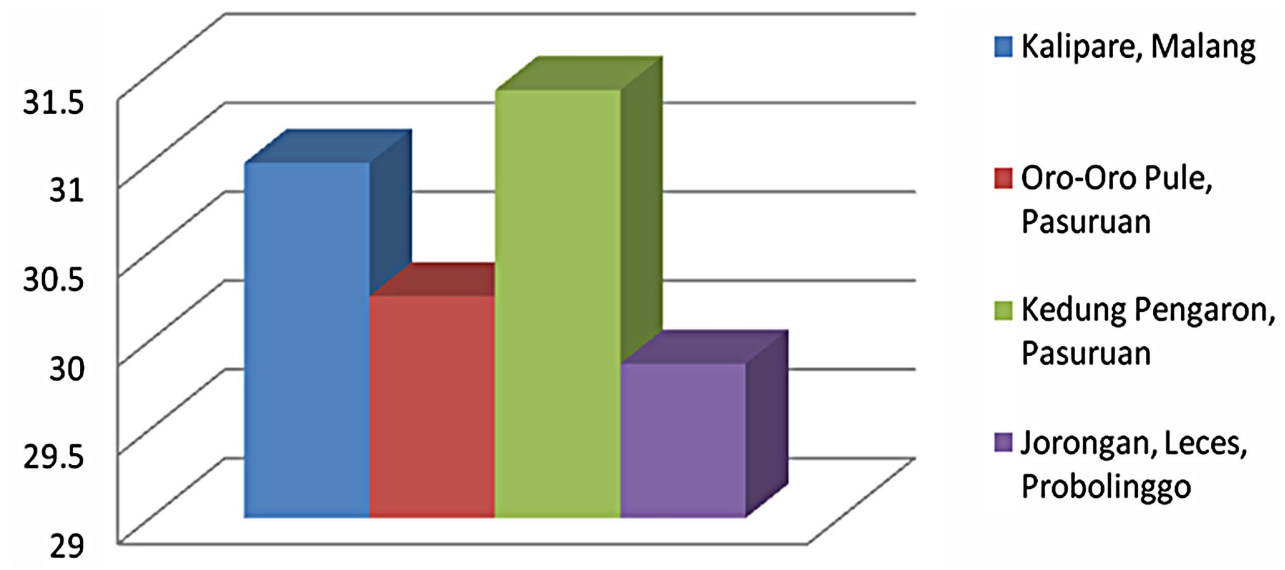

Figure 6. The average of seeds oil content (\%) of physic nut hybrids in four dry lands.

in the castration. The stamen of Jatropha plant can be found inside the male flower while the pistil can be found inside the female flower, therefore it is highly possible to do the crossing easily. However, until nowadays, the process of crossing the Jatropha plant has not commonly been done yet and the success of the process of the Jatropha plant's crossing is determined by the castrated process, pollination, and age of the female flower. The good pollen comes from the fresh male flower with yellow color and aged not more than one day [13].

Up to now, the actual production level of Jatropha is still much lower than its potential. [4] identified seven accessions Jatropha which has high productivity expectations, the HS49 (1097.50 kg/ha), SP16 (977.50 kg/ha), SP38 (912.50 kg/ha), SP8 (656.07 kg/ha), SM-33 (622.50 kg/ha), SP-34 (578.33 kg/ha), and SM35 (500 $\mathrm{kg} / \mathrm{ha})$. From the mass selection, it has produced IP-1 which has been generated by the production potential of 4 - 5 tons/ha, in 5th year and IP-2 with a potential production of 7 - 8 tonnes/ha in 5th year [3]. This research was conducted on marginal lands that have limited sources of water, therefore the cultivation process was conducted without watering (it is only depending on the rainy season). In this research activities, the selected planting sites did not get rain from the end of March 2012 to October 2012. The plants' strength to survive in minimum water condition depends on the plants rooting conditions. Jatropha plants have roots that spread throughout the underground, able to penetrate the layers of soil and look for water resources that are deep into the ground, so it is resistant to the drought and able to grow on marginal lands [14].

The collected data from the research results shows that the variety of plants' seeds production level from one 
hybrid number nor one of their parental in different planting sites is enormous. As an example, the hybrid between SP38XHS49 produces $1170 \mathrm{~kg} /$ hectare average of seeds dry weight in Kedung Pengaron land, Pasuruan. However, in Oro-oro pule- Kejayan, Pasuruan, the hybrid only produces $255 \mathrm{~kg} /$ hectare of seeds dry weight. According to [15] the combination of environmental factors, genetics and physiological, have a role in determining the potential of plant production.

Jatropha requires a rainfall of at least $600 \mathrm{~mm} /$ year [16]. In the areas where the humidity is not become the limit factor (for example: drainage or enough rainfall) Jatropha can be productive all year, but can not stand in water saturated soil conditions. Although the dry climate of increasing seed oil content, the prolonged drought causes Jatropha leaves fall to save water that would cause the stagnation of growth and if it grows is very dry areas, generally not more 2 - $3 \mathrm{~m}$ high [17]. Furthermore, considering the important role of water and the high needs for water, the plant requires a constant source of water for its growth and development. From the observations, the average data of seed production per hectare at each location shows that the plants which are grown in Jorongan, Leces Probolinggo, produces more seeds compare to the other three planting sites. The environmental conditions of Jatropha's growing needs highly nutrients, water, and sufficient oxygen by the time the seeds are germinated until the harvest time. In the phase after antesis up to the fruit's formation, fruit's filling, and fruit's maturation needs highly nutrients and water.

Jatropha plant has the ability to grow on marginal land, however to be able to grow and produce the optimal distance of the plants require fertilization. On the development of Jatropha plants in dry land where it is not possible to perform watering or drainage, the planting was performed by using 1 - 2 month old seeds that are planted at the beginning of the rainy season. Giving organic matter on plant holes plays an important role to keep the soil humidity around the roots. According to [18], at the extensive cultivation in rain fed areas, water storage techniques is needed to be done in the rainy season which can then be used to water the plants in the dry season.

Jatropha seeds contain approximately $25 \%$ - 30\% oil and from the kernel contain $50 \%-60 \%$ oil [19]. [20] explain that Jatropha seed oil content is quite high so that it can be used to substitution of diesel oil. Figure 5 shows the oil content of some number of Jatropha's hybrids results (\%) from various plant sites. The data shows the resulting seed oil content ranged from 27.04 to 35.24 percent. The highest content of seed oil achieved by the crossing between SM35 $\times$ SP38 (32.035\%).

The process of flowers pollination on the Jatropha plant is less in unison, so the fruit harvest was done in stages according to the fruit level of maturity. Jatropha fruit can be harvested when the color of fruit skin turns to yellow. The way of individuals harvesting that is based on its skin color is an effective way of harvesting the fruit. The result of the research showed that the jatropha seeds that are harvested when the fruit is yellow can produce oil content ranging between $28 \%$ - 30\% [21].

\section{CONCLUSIONS}

The results showed that SP38XHS49 hybrid on field Kedung Pengaron, produces the highest seeds dry weight per hectare $(1170 \mathrm{~kg} / \mathrm{ha})$ with dry weight of 100 seeds (62.33 gram) and the oil content is $32.56 \%$. The highest average of dry seed productions from all planting sites achieved on the crossing between SP38XHS49 (658.75 $\mathrm{kg} /$ hectare) and followed by SP8XHS49 (607.5 kg/hectare). If the comparison of the four locations, the highest average productivity of Jatropha plants achieved on location Jorongan, Leces, Probolinggo. In general, the data proves that the hybrid result from the crossing shows the higher production level compare to their parental.

The dry weight of 100 seeds produced ranged from 54.03 grams to 68.29 grams. Of all four planting sites, it shows that the highest 100 seeds dry weight achieved by the crossing between IP1PXHS49 which is 64.63 grams. The seed oil content ranged from 27.04 to 35.24 percent. The highest average of seed oil content achieved by the crossing between SM35XSP38 (32.035\%).

\section{ACKNOWLEDGEMENTS}

My thanks to The Directorate of Research and Community Services, The General Directorate of High Education, The National Department of Education Republic of Indonesia, which have supported the research fund through the program of Mainstay Research on Universities and Industry in 2010 and 2011. Awards are also presented to the head and staff of the Center of Tobacco and Fiber Research and PT. Alegria Indonesia for all the support of research facilities.

\section{REFERENCES}

[1] Agency for the Assessment and Technology Development (2006) Biodisel. http://ec.bppt. go.id/biodiesel/index.htm.

[2] Hasnam and Machmudi (2005) Jatropha curcas seeding guide. Plantation research and Development Center, Department of Agriculture Indonesia, Bogor, 9-14.

[3] Hasnam (2006) The status of the repair and supply of planting material of Jatropha curcas. Proceedings of the Workshop II: Status of Jatropha Plant Technology, Bogor, 29 November 2006, 36-38.

[4] Sudarmo, H.B., Heliyanto, Suwarso and Sudarmadji (2007) Potential accessions of Jatropha curcas Linn. Proceedings of the Workshop II: Status of Jatropha Plant Technology, Bogor, 29 November 2007, 104-106.

[5] Sri Yulaikhah and Kholid, M (2012) Hybridization of Ja- 
tropha curcas Linn. high production and resistant to water limitations accession. National Workshop on Plant Sweeteners, Fibers, Tobacco and Oil Industry, Agency for Agricultural Research and Development, Malang, 9799.

[6] Agency Research and Development of Agricultural Land Resources (2006) Potential lands for the development of biofuel crops. Jakarta, 3-6.

[7] Chalal, G.S. and Gosal (2006) Principles and procedure of plant breeding. In: Biotechnological and Conventionnal Approaches, 3rd Edition, Alpha Science, Hayward.

[8] Maftuchah, B.H., Agus, Z. and Hadi, S. (2008) Genetic diversity of some Accession Potential Jatropha curcas L. Based on random amplified polymorphic DNA. In: Proceedings of the National Workshop IV Jatropha: Jatropha curcas Technology Acceleration Invovasi toward Energy Independence, Surya Pena Publishing, Malang, 69-78.

[9] Maftuchah (2009) Development of new potentials energy in Indonesia. International Workshop on Regional Cooperation to Address Climate Change (Cambodia, Indonesia, Korea, Philippines). Korea Energy Economics Institute, Cambodia Ministry on Environment, Siem Reap, 2123 September 2009.

[10] Maftuchah (2010) Development of Jatropha curcas L. plantation and biodiesel production. Collaboration Workshop on Sustainable Energy Development, EN3EN Co. Ltd. Korea \& Center for Energy Environment and Regional Development, Mataram, 7-15 September 2010.

[11] Akpan, U.G., Jimoh, A. and Mohammed, A.D. (2006) Extraction, characterization and modification of castor seed oil. Leonardo Journal of Sciences, 43-52.

[12] Heller J. (1996) Physic nut, Jatropha curcas L. Promoting the conservation and use of underutilized and neglected crops 1. Institute of Plant Genetic and Crop Plant Research, Gatersleben, Germany.
[13] Hartati, R.S. (2008) Some important properties for the improvement of Jatropha plant varieties. Proceedings of the Workshop III: Innovation Jatropha Technology to Support Energy Independent Village, Malang, 5 November 2007, 66-69.

[14] Prihandana, R. and Hendoko, R. (2006) Jatropha curcas Linn. cultivation. PT Agromeda Pustaka, Jakarta.

[15] Gour, V.K. (2006) Production practice including post harvest management of Jatropha curcas L. Biodiesel Conference toward Energy Independence-Focus on Jatropha. New Delhi, 9-10 June 2006, 223-251.

[16] Henning, R.K. (2004) Jatropha curcas L. in Africa. Case Study. Weissenberg.

[17] Jones, N. and Miller, J.H. (1992) Jatropha curcas: A multipurpose species for problematic sites. The World Bank, Washington DC, 57-59.

[18] Romli, M.B., Hariyono and Machfud, M. (2007) Effect of fertilizer N, P and K. on the growth and yield of Jatropha curcas L. Proceedings of the Workshop II: Status of Jatropha Plant Technology, Bogor, 30-35.

[19] Lele, S. (2005) The cultivation of Jatropha curcas. Research J-22, Sector, Vashi, Navi Mumbai.

[20] Estate Crops Research and Development Centre (2006) Information technology Jatropha curcas L. badan penelitian dan pengembangan pertanian. Agency for Agricultural Research and Development. Estate Crops Research and Development Centre, Bogor, 5-6.

[21] Wanita, Y.P. and Hartono, J. (2007) Effect of fruit maturity level of the oil content of Jatropha (Jatropha curcas L.). Proceedings of the Workshop II: Status of Jatropha Plant Technology, Agency for Agricultural Research and Development, Estate Crops Research and Development Centre, Bogor, 177-180. 